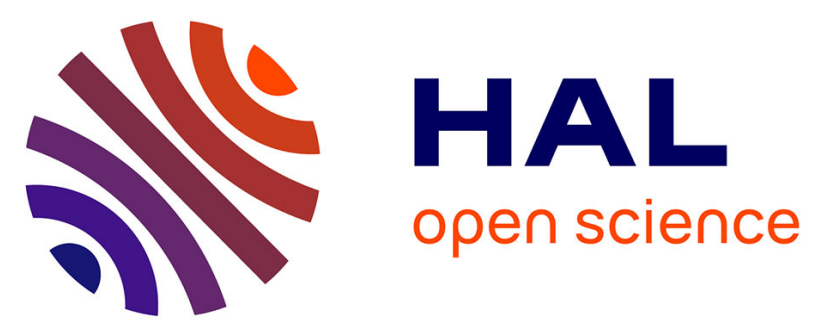

\title{
Renal organic anion transporters OAT1 and OAT3 mediate the cellular accumulation of 5 -sulfooxymethylfurfural, a reactive, nephrotoxic metabolite of the Maillard product 5-hydroxymethylfurfural
}

Nadiya Bakhiya, Bernhard Monien, Heinz Frank, Albrecht Seidel, Hansruedi Glatt

\section{- To cite this version:}

Nadiya Bakhiya, Bernhard Monien, Heinz Frank, Albrecht Seidel, Hansruedi Glatt. Renal organic anion transporters OAT1 and OAT3 mediate the cellular accumulation of 5-sulfooxymethylfurfural, a reactive, nephrotoxic metabolite of the Maillard product 5-hydroxymethylfurfural. Biochemical Pharmacology, 2009, 78 (4), pp.414. 10.1016/j.bcp.2009.04.017 . hal-00493520

\author{
HAL Id: hal-00493520 \\ https://hal.science/hal-00493520
}

Submitted on 19 Jun 2010

HAL is a multi-disciplinary open access archive for the deposit and dissemination of scientific research documents, whether they are published or not. The documents may come from teaching and research institutions in France or abroad, or from public or private research centers.
L'archive ouverte pluridisciplinaire HAL, est destinée au dépôt et à la diffusion de documents scientifiques de niveau recherche, publiés ou non, émanant des établissements d'enseignement et de recherche français ou étrangers, des laboratoires publics ou privés. 


\section{Accepted Manuscript}

Title: Renal organic anion transporters OAT1 and OAT3 mediate the cellular accumulation of 5-sulfooxymethylfurfural, a reactive, nephrotoxic metabolite of the Maillard product 5-hydroxymethylfurfural

Authors: Nadiya Bakhiya, Bernhard Monien, Heinz Frank,

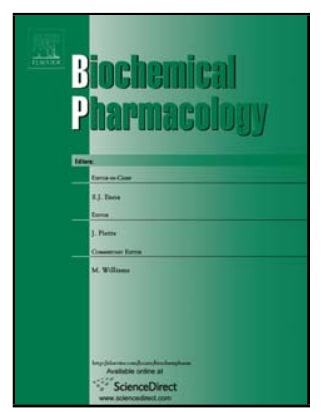
Albrecht Seidel, Hansruedi Glatt

PII: S0006-2952(09)00302-5

DOI: doi:10.1016/j.bcp.2009.04.017

Reference: BCP 10156

To appear in: $\quad B C P$

Received date: $\quad 30-1-2009$

Revised date: $\quad$ 16-4-2009

Accepted date: $\quad$ 16-4-2009

Please cite this article as: Bakhiya N, Monien B, Frank H, Seidel A, Glatt $\mathrm{H}$, Renal organic anion transporters OAT1 and OAT3 mediate the cellular accumulation of 5-sulfooxymethylfurfural, a reactive, nephrotoxic metabolite of the Maillard product 5-hydroxymethylfurfural, Biochemical Pharmacology (2008), doi:10.1016/j.bcp.2009.04.017

This is a PDF file of an unedited manuscript that has been accepted for publication. As a service to our customers we are providing this early version of the manuscript. The manuscript will undergo copyediting, typesetting, and review of the resulting proof before it is published in its final form. Please note that during the production process errors may be discovered which could affect the content, and all legal disclaimers that apply to the journal pertain. 


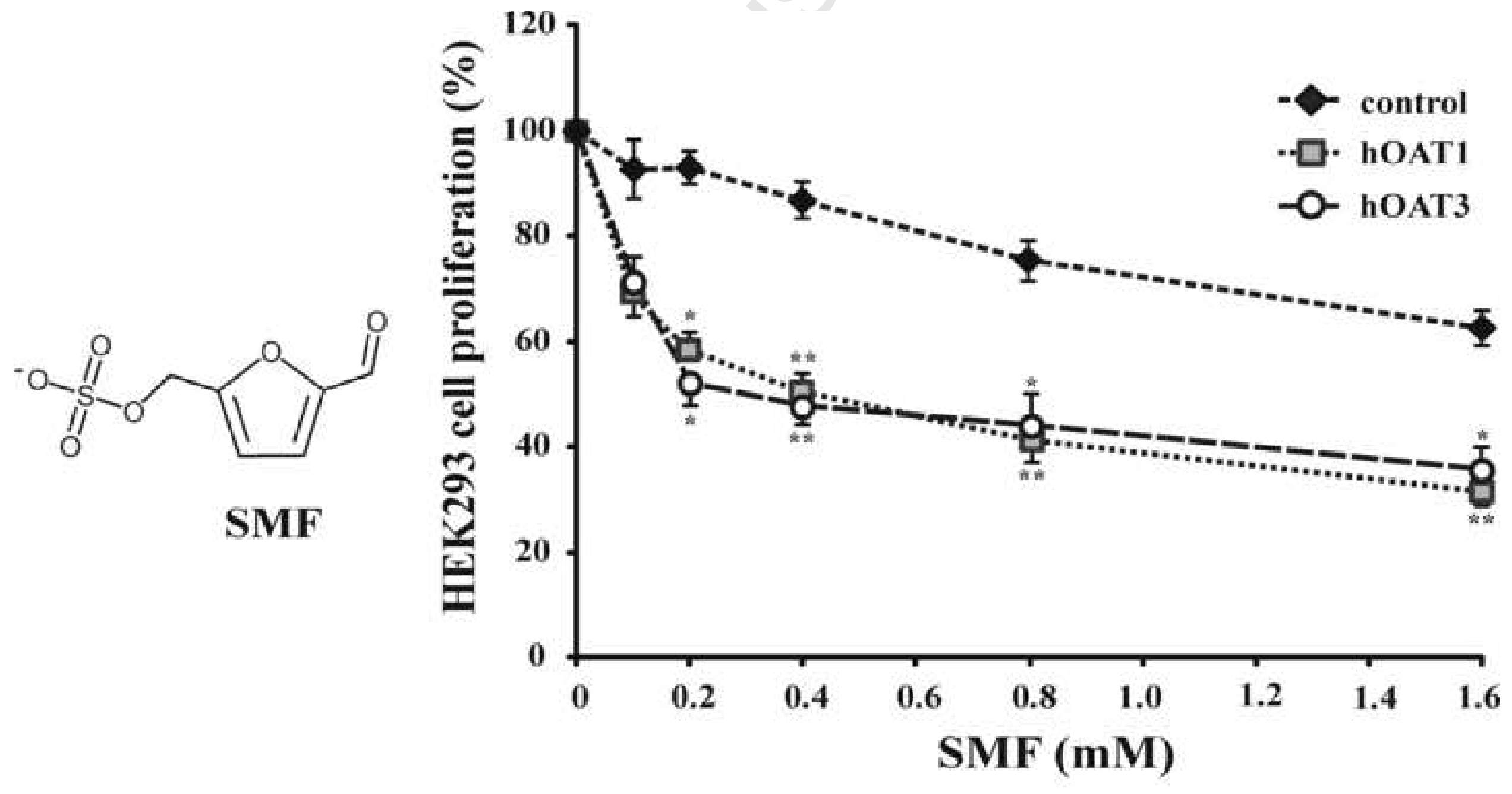

Cytotoxicity of 5-sulfooxymethylfurfural (SMF) in control and human OAT-expressing cells 


\section{Renal organic anion transporters OAT1 and OAT3 mediate the cellular accumulation of 5-sulfooxymethylfurfural, a reactive, nephrotoxic metabolite of the Maillard product 5-hydroxymethylfurfural}

Nadiya Bakhiya, Bernhard Monien, Heinz Frank ${ }^{1}$, Albrecht Seidel ${ }^{1}$ and Hansruedi Glatt*

German Institute of Human Nutrition Potsdam-Rehbrücke, Department of Nutritional Toxicology, 14558 Nuthetal, Germany

1 Biochemical Institute for Environmental Carcinogens, Prof. Dr. Gernot Grimmer Foundation, 22927 Grosshansdorf, Germany

\section{* Address correspondence to:}

Prof. Dr. H. R. Glatt

German Institute of Human Nutrition Potsdam-Rehbrücke,

Department of Nutritional Toxicology

14558 Nuthetal, Germany

Phone: $\quad+493320088321$

Fax: $\quad+493320088426$

e-mail: glatt@dife.de 


\section{Abstract}

5-Hydroxymethylfurfural (HMF) is formed when sugars are acidified or heated. It is present at high levels in numerous foods. HMF is inactive in standard genotoxicity tests, but can be metabolized to a chemically reactive intermediate, 5-sulphooxymethylfurfural (SMF), which is mutagenic and carcinogenic. We recently found that direct parental administration of SMF to mice leads to abundant acute necrosis and proteinaceous casts in the proximal tubules as the dominating toxicological effect. Since proximal tubule cells actively mediate the excretion of many organic anions, we hypothesized that transporter-mediated uptake of SMF into the cells could be the reason for this selective organotoxicity. To test this hypothesis, we used human embryonic kidney (HEK293) cells stably expressing human (h) OAT1 or OAT3. SMF was a competitive inhibitor of $p$-aminohippurate uptake by hOAT1 and estrone sulfate uptake by hOAT3 with $K_{\mathrm{i}}$ values of $225 \mu \mathrm{M}$ and $1.5 \mathrm{mM}$, respectively. Moreover, the initial rates of SMF uptake were 5.2- and 3.1-fold higher in cells expressing hOAT1 and hOAT3, respectively, than in control HEK293 cells. Likewise, the sensitivity of hOAT1- and hOAT3expressing cells to SMF cytotoxicity was significantly higher than that of control cells, and was reduced by addition of probenecid, an inhibitor of OATs. Taken together, these results indicate that OAT1 and OAT3 mediate the uptake of SMF into proximal tubule cells and thereby may be involved in SMF-induced nephrotoxicity.

Key Words: 5-hydroxymethylfurfural, 5-sulfooxymethylfurfural, nephrotoxicity, organic anion transporters 
Abbreviations: HMF, 5-hydroxymethylfurfural; hOAT, human organic anion transporter;

OAT, organic anion transporter; SMF, 5-sulfooxymethylfurfural; SULT, sulfotransferase;

UPLC, ultra performance liquid chromatography. 


\section{Introduction}

5-(Hydroxymethyl)-2-furfural (HMF) is one of the numerous compounds resulting from the heating of foods. It is formed when reducing hexose moieties are heated in the presence of amino acids or proteins (Maillard reaction) [1] and via direct thermal dehydration of fructose, sucrose and glucose [2]. HMF is present at high levels in many foods, with particularly high concentrations found in caramel products (up to $9.5 \mathrm{~g} / \mathrm{kg}$ ), dried fruit (especially plums), old Port and Madeira wines, and balsamic vinegar [3-5]. However, coffee may be a major source of HMF intake in many subjects due to the high amount consumed [5]. The estimated daily intake is in the range of $30-150 \mathrm{mg}$ per person $[6,7]$. Although HMF is inactive in standard in vitro genotoxicity tests $[7,8]$, it induced and promoted preneoplastic lesions, aberrant crypt foci, in rat colon [9] and initiated papillomas in mouse skin [10]. Furthermore, in a long-term carcinogenicity study conducted by National Toxicology Program, HMF was found to increase the incidence of hepatocellular adenomas in female mice [11].

Numerous chemicals are mutagenic or carcinogenic after metabolic activation to chemically reactive intermediates. HMF is converted to a chemically reactive allylic ester, 5sulfooxymethylfurfural (SMF, structural formula depicted in Fig. 1) by sulfotransferases (SULT), enzymes ignored in standard in vitro genotoxicity tests. HMF showed mutagenic activity when tested in bacterial and mammalian target cells engineered for expression of human SULT1A1 [8]. SMF, unlike HMF, formed DNA adducts in cell-free systems and was mutagenic to bacterial and mammalian cells without requiring an activating system $[8,12]$. When administered topically to mouse skin, SMF initiated papillomas with higher activity than HMF [10]. 
In a recent study conducted in our laboratory SMF was found to be strongly nephrotoxic in the mouse in vivo (F. Taugner, S. Florian and H. R. Glatt, manuscript in preparation). Male FVB/N mice which received a single dose of SMF (250 mg SMF / $\mathrm{kg}$ body mass, i.p.) died or were moribund 5-11 days after the treatment. Histopathological analyses revealed that SMF induced moderate damage in liver and most impressive damage in the kidneys, particularly in the proximal tubules, where abundant necrosis and proteinaceous casts were observed. While nearly all proximal tubules in SMF-exposed animals were destroyed, distal tubules and glomeruli were less affected. The molecular mechanism underlying this selective toxicity of SMF in proximal tubules is unknown.

An important physiological function of the proximal tubule is the secretion of a large variety of organic anions, including endogenous catabolites, drugs and other xenobiotics [13]. The organic anion transporters OAT1 and OAT3 are localized at the basolateral membrane of proximal tubule cells and mediate the concentrative uptake of their substrates from blood into renal proximal tubule cells, which is the rate-limiting step in this excretion system [14]. Genes of both transporters were cloned from several species, including rat and man, and are highly conserved across species $[14,15]$. Both transporters show overlapping substrate specificities and share the driving force - exchange of organic anions against intracellular $\alpha$-ketoglutarate. Moreover, the activity of OAT1 and OAT3 has been associated with proximal tubular injury due to the accumulation of toxicants, such as uremic toxins, mercuric species and ochratoxin A [16], as well as genotoxic benzylic sulfates formed from alkylated polycyclic aromatic hydrocarbons [17].

The aim of the present investigation was to determine the possible involvement of OAT1 and OAT3 in the uptake, accumulation and toxicity of SMF in renal cells. To this end, we used 
human embryonic kidney cells (HEK293) stably expressing human (h) OAT1 or OAT3 to assess both uptake and toxicity of SMF.

\section{Materials and methods}

\subsection{Chemicals}

5-Hydroxymethylfurfural, sulfur trioxide-pyridine complex, sodium methoxide, and the anhydrous solvents tetrahydrofuran, diethyl ether, and dimethylformamide were purchased from Sigma-Aldrich (Taufkirchen, Germany) and used as received. All solvents for UPLC were purchased from Carl Roth GmbH (Karlsruhe, Germany). Cell culture reagents were from Gibco Invitrogen (Karlsruhe, Germany), unless specified otherwise. [6,7- $\left.{ }^{3} \mathrm{H}(\mathrm{N})\right]$ Estrone sulfate $(57.3 \mathrm{Ci} / \mathrm{mmol})$ and $\left[\right.$ glycyl-2- $\left.{ }^{3} \mathrm{H}\right] p$-aminohippurate $(4.18 \mathrm{Ci} / \mathrm{mmol})$ were purchased from Perkin-Elmer (Boston, USA). The specific radioactivity of $\left[{ }^{3} \mathrm{H}\right] p$-aminohippurate was reduced to $0.5 \mathrm{Ci} / \mathrm{mmol}$ by adding unlabeled $p$-aminohippurate. [Methyl- ${ }^{3} \mathrm{H}$ ] thymidine $(20$ $\mathrm{Ci} / \mathrm{mmol}$ ) was purchased from MP Biomedicals (Illkirch Cedex, France).

NMR spectra were obtained on a Bruker AV400 spectrometer at the University of Hamburg. Melting points (mp) were determined on a Büchi 510 apparatus.

\subsection{Synthesis of SMF}

5-Hydroxymethylfurfural $(0.032 \mathrm{~g} ; 0.25 \mathrm{mmol})$ was dissolved in $1 \mathrm{ml}$ anhydrous tetrahydrofuran and this solution was cooled to $0^{\circ} \mathrm{C}$. After addition of a solution of $80 \mathrm{mg}$ sulfur trioxide-pyridine complex $(0.5 \mathrm{mmol})$ in $0.65 \mathrm{ml}$ anhydrous $N, N$-dimethylformamide the mixture was stirred at $0^{\circ} \mathrm{C}$ for 4 hours. Then a solution of $40 \mathrm{mg}(0.74 \mathrm{mmol})$ sodium 
methoxide in $0.35 \mathrm{ml}$ methanol was added and the resulting mixture was centrifuged. The supernatant was added dropwise to $80 \mathrm{ml}$ of anhydrous diethyl ether. The formed precipitate was filtered off, washed with anhydrous diethyl ether, and dried under vacuum to give a yield of $0.043 \mathrm{~g} \mathrm{SMF} \mathrm{(75 \%} \mathrm{yield);} \mathrm{mp} 128{ }^{\circ} \mathrm{C}$ (dec); ${ }^{1} \mathrm{H}-\mathrm{NMR}(400 \mathrm{MHz}, \mathrm{DMSO}-\mathrm{d} 6) \delta$ [ppm] 9.63 (s, 1, CHO), $7.54\left(\mathrm{~d}, 1, \mathrm{H}_{3}, J_{3,4}=3.6 \mathrm{~Hz}\right), 6.75\left(\mathrm{~d}, 1, \mathrm{H}_{4}, J_{4,3}=3.6 \mathrm{~Hz}\right), 4.83\left(\mathrm{~s}, 2,-\mathrm{CH}_{2}-\mathrm{O}\right)$. The purity of SMF was greater than $99 \%$ as determined by liquid chromatography-mass spectrometry (see section 2.5).

\subsection{Tissue culture}

hOAT1 and hOAT3 were stably expressed in the human embryonic kidney cell line HEK293 as described previously [17]. Cells were grown in flasks containing Dulbecco's modified minimum essential medium (high glucose) supplemented with fetal bovine serum (10\%, Biochrom AG, Berlin, Germany), penicillin (100 units $/ \mathrm{ml})$ and streptomycin (100 $\mu \mathrm{g} / \mathrm{ml})$. The medium for the recombinant cells, but not for parental HEK293 cells, additionally contained hygromycin $(175 \mu \mathrm{g} / \mathrm{ml})$. Cultures were maintained in a humidified atmosphere containing 5 $\% \mathrm{CO}_{2}$ at $37^{\circ} \mathrm{C}$. Cultures were split in a 1:5 ratio every third to forth day.

\subsection{Inhibition of uptake of standard substrates}

Cells were seeded in 24-well plates ( $2 \times 10^{5}$ cells in $1 \mathrm{ml}$ medium per well) two days before the experiment. Uptake of $\left[{ }^{3} \mathrm{H}\right] p$-aminohippurate (for OAT1) and $\left[{ }^{3} \mathrm{H}\right]$ estrone sulfate (for hOAT3) was assayed at $37^{\circ} \mathrm{C}$ in Ringer's solution (130 $\mathrm{mM} \mathrm{NaCl}, 4 \mathrm{mM} \mathrm{KCl}, 1 \mathrm{mM} \mathrm{CaCl}_{2}, 1$ $\mathrm{mM} \mathrm{MgSO}_{4}, 20 \mathrm{mM}$ HEPES, $1 \mathrm{mM} \mathrm{NaH}_{2} \mathrm{PO}_{4}, 18 \mathrm{mM}$ glucose, $\mathrm{pH}$ 7.4) for $2 \mathrm{~min}$ in the absence or presence of SMF. The uptake was terminated by three washes with $0.5 \mathrm{ml}$ of icecold Ringer's solution. Cells were then solubilized in $0.5 \mathrm{ml}$ of $1 \mathrm{~N} \mathrm{NaOH}$. After 
neutralization with $0.5 \mathrm{ml}$ of $1 \mathrm{~N} \mathrm{HCl}$, their ${ }^{3} \mathrm{H}$ content was assayed by liquid scintillation counting. The results were standardized to the level of protein determined using the bicinchoninic acid assay (Pierce, Rockford, USA) with bovine serum albumin as the standard. For quantifying the inhibitory activity, we used varying concentrations of the substrate (10 and $50 \mu \mathrm{M}\left[{ }^{3} \mathrm{H}\right] p$-aminohippurate for hOAT1; 50 and $250 \mathrm{nM}\left[{ }^{3} \mathrm{H}\right]$ estrone sulfate for hOAT3) and SMF ( $\geq 5$ concentrations, up to $1 \mathrm{mM}$ for hOAT1 and $2 \mathrm{mM}$ for hOAT3). Data were plotted and analyzed according to Dixon [18].

\subsection{LC-MS/MS analysis of SMF uptake into cells}

Cells were incubated in Ringer's solution containing $250 \mu \mathrm{M} \mathrm{SMF}$ at room temperature for 1$15 \mathrm{~min}$. After three washes with ice-cold Ringer's solution, the cells were lysed with $0.25 \mathrm{ml}$ $1 \mathrm{~N} \mathrm{NaOH}$ and, after neutralization with $0.25 \mathrm{ml}$ of $1 \mathrm{~N} \mathrm{HCl}$ and protein precipitation with 1 $\mathrm{ml}$ of ice-cold 2-propanol, mixed thoroughly and centrifuged at $15,000 \mathrm{~g}$ for $15 \mathrm{~min}$. The clear supernatant was analyzed using an Acquity ultra performance liquid chromatography (UPLC) System (Waters, Milford, Massachussetts, USA) with a UPLC BEH Phenyl column $(1.7 \mu \mathrm{m}, 2.1 \times 100 \mathrm{~mm}$, Waters). Samples of $4 \mu \mathrm{l}$ were injected, and SMF was eluted with 10 $\mathrm{mM}$ ammonium acetate/methanol $(95: 5)$ at $0.35 \mathrm{ml} / \mathrm{min}$ flow rate. The UPLC was connected to a Quattro Premier XE tandem quadrupole mass spectrometer (Waters Micromass, Manchester, UK) with an electrospray interface operated in the negative ion mode. Two fragmentation reactions of SMF were monitored, yielding the sulfate ion radical $(204.9 \rightarrow 96)$ and the protonated sulfonate ion $(204.9 \rightarrow 81)$. The tune parameter were as follows: temperature of the electrospray source $120^{\circ} \mathrm{C}$; desolvation temperature $500^{\circ} \mathrm{C}$; desolvation gas: nitrogen ( $8501 / \mathrm{h})$; cone gas: nitrogen $(100 \mathrm{l} / \mathrm{h})$; collision gas: argon (indicated cell pressure $\sim 5 \cdot 10^{-3}$ mbar). For the fragmentation of SMF, collision energies were 18 and $22 \mathrm{eV}$ 
for the transitions $204.9 \rightarrow 81$ and $204.9 \rightarrow 96$, respectively. The dwell time was set to 100 $\mathrm{ms}$, and capillary voltage was set to $0.35 \mathrm{kV}$. The cone and RF1 lens voltages were $32 \mathrm{~V}$ and $0.1 \mathrm{~V}$, respectively. SMF was quantified using an external calibration line prepared in water/2-propanol (1:3). The calibration curves were linear in the range between $500 \mathrm{nM}(2$ pmol/injection) and $1 \mathrm{nM}(4 \mathrm{fmol} /$ injection $) \operatorname{SMF}\left(\mathrm{r}^{2} \geq 0.993\right)$. Details of the method has been published elsewhere [22].

\section{6. $\left[{ }^{3}\right.$ H]Thymidine-incorporation proliferation assay}

Cells $\left(1 \times 10^{5}\right.$ cells per well) were seeded in 24 -well plate $24 \mathrm{~h}$ before starting exposure. Then, they were incubated at $37^{\circ} \mathrm{C}$ for $1 \mathrm{~h}$ in the absence or presence of various concentrations of SMF (0.1-1.6 mM). After the incubation, cells were washed twice with medium. $\left[{ }^{3} \mathrm{H}\right]$ Thymidine $(0.2 \mu \mathrm{Ci} / \mathrm{ml}$ in culture medium $)$ was incorporated at $37^{\circ} \mathrm{C}$ for $1 \mathrm{~h}$. The cells were fixed with $5 \%$ trichloroacetic acid $\left(30 \mathrm{~min}\right.$ at $\left.4{ }^{\circ} \mathrm{C}\right)$, washed twice with icecold PBS and once with of ice-cold $95 \%$ ethanol to remove unused $\left[{ }^{3} \mathrm{H}\right]$ thymidine. For the solubilization of the genomic DNA, the cells were incubated with $0.5 \mathrm{ml}$ of $1 \mathrm{~N} \mathrm{NaOH}$ overnight. After neutralization with $0.5 \mathrm{ml}$ of $1 \mathrm{~N} \mathrm{HCl}$, the ${ }^{3} \mathrm{H}$ content was assayed by liquid scintillation counting.

\section{Results}

\subsection{Inhibition of hOAT1 and hOAT3 by SMF}

SMF was tested for its ability to inhibit hOAT-mediated uptake of model substrates, $p$ aminohippurate for hOAT1 and estrone sulfate for hOAT3 in recombinant embryonic kidney 
cells. As shown in Fig. 2, SMF inhibited substrate uptake by both hOATs. The effect increased with the concentration of SMF. The sensitivities of hOAT1- and hOAT3-mediated substrate uptakes to SMF inhibition were different. At a concentrations of 0.5 and $1 \mathrm{mM}$, SMF inhibited $p$-aminohippurate $(10 \mu \mathrm{M})$ uptake by hOAT1-expressing cells by $68 \%$ and 79 $\%$, respectively (Fig. 2A). In the presence of the same SMF concentrations ( 0.5 and $1 \mathrm{mM})$ estrone sulfate $(50 \mathrm{nM})$ uptake by hOAT3-cells was inhibited somewhat less (by $27 \%$ and 45 $\%$, respectively, Fig. 2 B).

Subsequently, we studied the inhibition kinetics of SMF using different concentrations of the model substrates and SMF. The $K_{\mathrm{i}}$ values were determined from Dixon plots. Representative plots are shown in Fig. 3. Similar results were obtained in repeat experiments. SMF competitively inhibited the organic anion transport mediated by both transporters. The mean $K_{\mathrm{i}}$ value $( \pm \mathrm{SE})$ of SMF for hOAT1 was determined at $225 \pm 22 \mu \mathrm{M}(245,248$ and $182 \mu \mathrm{M}$ in three experiments). The corresponding value for hOAT3 was $1.46 \pm 0.04 \mathrm{mM}(1.38,1.53$ and $1.47 \mathrm{mM}$ in three experiments).

\section{2. hOAT1- and hOAT3-mediated uptake of SMF into cells}

To test whether SMF is transported by hOAT, we exposed parental HEK293 and transporterexpressing cells to SMF $(250 \mu \mathrm{M})$ for 1-15 min and then analyzed the intracellular SMF content by UPLC-MS/MS. The analytical method used was highly specific and sensitive (limit of detection $\sim 5 \mathrm{fmol}$ per injection). As shown in Fig. 4A, the uptake was linear with time for at least 4-10 min in all three cell lines. The initial slopes amounted to 1.3, 6.6 and 3.9 nmol/mg protein/min for control, hOAT1- and hOAT3-expressing cells respectively. Thus, expression of hOAT1 and hOAT3 enhanced the uptake rates by a factor of 5.2 and 3.1, 
respectively. Moreover, the SMF uptake by hOAT-expressing cells was inhibited by addition of probenecid (a known inhibitor of OAT) to the incubation medium, indicating that this uptake was hOAT-mediated (Fig. 4B).

\subsection{Influence of hOAT1 and hOAT3 expression on cellular toxicity of SMF}

As shown in Fig. 5, hOAT1 and hOAT3-expressing were markedly more sensitive than control cells to toxic effects of SMF. The difference was significant for both transporters starting from $0.2 \mathrm{mM}$ SMF concentration. The enhanced cytotoxicity of hOAT-expressing cells to SMF was directly related to the activity of the expressed transporters, as demonstrated using probenecid, an inhibitor of OATs. Probenecid markedly reduced of the cytotoxicity of SMF (0.4 mM) in the hOAT-expressing cells (Fig. 6). Survival of hOAT1-expressing cells was elevated by probenecid from $49 \%$ to $71 \%$. Similarly, survival of hOAT3-expressing cells was increased from $55 \%$ in the absence to $74 \%$ in the presence of probenecid.

\section{Discussion}

HMF can be activated to a chemically reactive and genotoxic metabolite, SMF. In a recent in vivo study we detected strong toxicity of SMF to renal proximal tubule cells leading to death in most animals after a single dose of $250 \mathrm{mg} / \mathrm{kg}$. At the next lower dose (125 mg/kg), animals developed an atypical renal hyperplasia. The proximal tubule cells are the primary sites of OAT1 and OAT3 expression, and previous studies suggest that these transporters could participate in accumulation of reactive sulfo conjugates in this tissue. 
The data reported here provide molecular evidence that hOAT1 and hOAT3 can mediate the uptake of SMF into renal cells. Both uptake and toxicity of SMF were significantly higher in HEK293 cells expressing hOAT1 or hOAT3 than in control cells lacking these transporters. Furthermore, both uptake and toxicity were reduced by the OAT inhibitor probenecid, indicating that SMF is a substrate of hOAT1 and hOAT3. Therefore, OAT1 and OAT3 seem to provide specific paths for the entry of SMF into renal cells, leading to proximal tubule damage. The affinities of SMF interaction with hOAT1 and hOAT3, measured in the inhibition study, were considerably different. The $\mathrm{K}_{\mathrm{i}}$ value of hOAT1 for SMF was in the range of $225 \mu \mathrm{M}$, while the affinity of the hOAT3 to SMF was approximately 7 times lower $\left(\mathrm{K}_{\mathrm{i}}\right.$ value $\left.\sim 1.5 \mathrm{mM}\right)$, suggesting that this transporter contributes less to cellular SMF uptake than hOAT1.

As shown in rodents, HMF is well absorbed from the gastro-intestinal tract, rapidly metabolized, and excreted primarily in urine. The principal urinary metabolites are 5hydroxymethyl-2-furoic acid and its glycine conjugate and furan-2,5-dicarboxylic acid [1921]. SMF was not detected in urine. However, SMF is chemically reactive, making its detection in biological samples difficult. The half-life time of SMF in aqueous solutions at $37^{\circ} \mathrm{C}$ amounts to nearly $2 \mathrm{~h}$. Recent studies conducted in our laboratory demonstrate the formation of SMF from HMF in the mouse in vivo [22]. SMF was detected in blood samples of FVB/N mice after intravenous administration of HMF. From a dose of $100 \mathrm{mg} \mathrm{HMF} / \mathrm{kg}$ body mass, approximately $0.04 \%$ HMF was metabolized to SMF and exported into the circulation; additional SMF may have been formed and reacted with cellular structures or hydrolyzed back to HMF at its side of formation not reaching the circulation. Several human SULT forms catalyze the sulfo conjugation of HMF with higher catalytic efficiency than murine enzymes; this is true in particular for SULT1A1, the most abundant SULT form in the 
human organism [8]. Therefore, it may be speculated that a higher percentage of HMF is converted to SMF in humans than in mice. Taking into consideration that the daily intake of HMF exceeds that of other food-borne pro-genotoxicants, such as acrylamide or heterocyclic amines, by factors of $10^{3}$ and $10^{5}$, respectively, conversion of a minute fraction to a reactive metabolite still could be toxicologically relevant.

Recently HMF was orally administrated to B6C3F1 mice and $\mathrm{F} 344 / \mathrm{N}$ rats to study its subacute, subchronic and chronic toxicity [11]. In a 3-month study, the incidence of cytoplasmic alterations of the kidney was significantly increased in male mice receiving 188 or $375 \mathrm{mg} / \mathrm{kg}$ HMF. In a 2-year carcinogenicity study, HMF showed evidence of carcinogenic activity, clearly increasing the incidence of hepatocellular adenomas in female mice receiving 188 or $375 \mathrm{mg} / \mathrm{kg} \mathrm{HMF}$. Thus, SMF formed in vivo in mice seems to cause the main damage at the site of its formation, the liver; probably only a minor part of SMF is exported to the blood. The situation in humans could be different, taking into consideration the speciesdependent differences in tissue distribution of HMF-activating SULTs, which are focused to the liver in mice, but widely expressed in numerous tissues in humans [23, 24].

Furfuryl alcohol is another common Maillard product. It only differs from HMF by the absence of the aldehyde group in 2 position. Like HMF, furfuryl alcohol is also activated to a mutagenic sulfo conjugate, furfuryl sulfate, by human SULTs [8]. Two-year carcinogenicity studies in male and female Fischer $344 / \mathrm{N}$ rats and $\mathrm{B} 6 \mathrm{C} 3 \mathrm{~F}_{1}$ mice had been conducted with furfuryl alcohol administrated by inhalation [25]. Notably, the incidence of renal tubule neoplasms was increased in male mice exposed to furfuryl alcohol, and the severity of nephropathy (typical for old mice and rats) was enhanced in both sexes of the rat as well as in male mice. We therefore suspect that the renal toxicity and carcinogenicity of furfuryl alcohol 
was mediated by its metabolite furfuryl sulfate, which is structurally related to SMF and thus could also be accumulated in the renal tubule cells by organic anion transporters.

Findings with some other chemicals indicate that kidneys might be a relatively common target tissue of reactive sulfo conjugates. 1-Sulfooxymethylpyrene is an ultimate mutagen and carcinogen formed from an abundant polycyclic aromatic hydrocarbon, 1-methylpyrene. After treating rats with 1-sulfooxymethylpyrene or its metabolic precursor, 1-hydroxymethylpyrene, the highest level of DNA adducts was detected in kidney [26]. Further in vitro studies showed that 1-sulfooxymethylpyrene is an excellent substrate for OAT1 and OAT3 [17].

Renal cell carcinomas account for approximately $3 \%$ of all adult malignancies [27]. The clear cell carcinoma, arising from proximal tubular cells, makes up 70 to $80 \%$ of renal neoplasias. The incidence of renal cell carcinomas varies more than 10 -fold between different countries and has been increasing in various countries, suggesting an involvement of exogenous factors. It would be interesting to know whether, and to which extent, HMF, furfuryl alcohol, alkylated polycyclic aromatic hydrocarbons and other SULT-dependent promutagens contribute to the induction of clear cell carcinomas.

In conclusion, in the present study we provide evidence for the involvement of organic anion transporters (OATs) in the renal accumulation of SMF. These transport characteristics could be responsible for the selective damage of renal proximal tubules by this reactive metabolite.

\section{Acknowledgements}


We thank Christine Gumz for her skillful technical assistance. This work has been carried out with support from the European Commission, Priority 5 on Food Quality and Safety (Contract nFOOD-CT-2003-506820 Specific Targeted Project), 'Heat-generated food toxicants identification, characterisation and risk minimisation'. A.S. and H.F. gratefully acknowledge financial support from ECNIS (Environmental Cancer Risk, Nutrition and Individual Susceptibility), a network of excellence operating within the European Union 6th Framework Program, Priority 5: "Food Quality and Safety" (Contract No 513943). 


\section{References}

[1] Mauron J. The Maillard reaction in food; a critical review from the nutritional standpoint. Prog Food Nutr Sci 1981;5:5-35.

[2] Antal MJ, Jr., Mok WS, Richards GN. Mechanism of formation of 5(hydroxymethyl)-2-furaldehyde from D-fructose and sucrose. Carbohydr Res 1990;199:91-109.

[3] Bachmann S, Meier M, Känzig A. 5-Hydroxymethyl-2-furfural (HMF) in Lebensmitteln. Lebensmittelchemie 1997;51:49-50.

[4] Murkovic M, Pichler N. Analysis of 5-hydroxymethylfurfual in coffee, dried fruits and urine. Mol Nutr Food Res 2006;50:842-6.

[5] Husøy T, Haugen M, Murkovic M, Jöbstl D, Stølen LH, Bjellaas T, et al. Dietary exposure to 5-hydroxymethylfurfural from Norwegian food and correlations with urine metabolites of short-term exposure. Food Chem Toxicol 2008;46:3697-702.

[6] Ulbricht RJ, Northup SJ, Thomas JA. A review of 5-hydroxymethylfurfural (HMF) in parenteral solutions. Fundam Appl Toxicol 1984;4:843-53.

[7] Janzowski C, Glaab V, Samimi E, Schlatter J, Eisenbrand G. 5Hydroxymethylfurfural: assessment of mutagenicity, DNA-damaging potential and reactivity towards cellular glutathione. Food Chem Toxicol 2000;38:801-9.

[8] Glatt HR, Sommer Y. Health risks by 5-hydroxymethylfurfural (HMF) and related compounds. In: Skog K, Alexander J, editors. Acrylamide and Other Health Hazardous Compounds in Heat-treated Foods. Cambridge: Woodhead Publishing, 2006. p. 328-57.

[9] Zhang XM, Chan CC, Stamp D, Minkin S, Archer MC, Bruce WR. Initiation and promotion of colonic aberrant crypt foci in rats by 5-hydroxymethyl-2-furaldehyde in thermolyzed sucrose. Carcinogenesis 1993;14:773-5.

[10] Surh YJ, Liem A, Miller JA, Tannenbaum SR. 5-Sulfooxymethylfurfural as a possible ultimate mutagenic and carcinogenic metabolite of the Maillard reaction product, 5hydroxymethylfurfural. Carcinogenesis 1994;15:2375-7.

[11] NTP. Toxicology and carcinogenesis studies of 5-(hydroxymethyl)-2-furfural (CAS No. 67-47-0) in F344/N rats and $\mathrm{B}_{6} \mathrm{C}_{3} \mathrm{~F}_{1}$ mice (gavage studies). Natl Toxicol Program Tech Report Series 2008 (draft available at http://ntp.niehs.nih.gov/) 
[12] Surh YJ, Tannenbaum SR. Activation of the Maillard reaction product 5(hydroxymethyl)furfural to strong mutagens via allylic sulfonation and chlorination. Chem Res Toxicol 1994;7:313-8.

[13] Russel FG, Masereeuw R, van Aubel RA. Molecular aspects of renal anionic drug transport. Annu Rev Physiol 2002;64:563-94.

[14] Burckhardt BC, Burckhardt G. Transport of organic anions across the basolateral membrane of proximal tubule cells. Rev Physiol Biochem Pharmacol 2003;146:95158.

[15] Robertson EE, Rankin GO. Human renal organic anion transporters: characteristics and contributions to drug and drug metabolite excretion. Pharmacol Ther 2006;109:399-412.

[16] Sweet DH. Organic anion transporter (Slc22a) family members as mediators of toxicity. Toxicol Appl Pharmacol 2005;204:198-215.

[17] Bakhiya N, Stephani M, Bahn A, Ugele B, Seidel A, Burckhardt G, et al. Uptake of chemically reactive, DNA-damaging sulfuric acid esters into renal cells by human organic anion transporters. J Am Soc Nephrol 2006;17:1414-21.

[18] Dixon M. The determination of enzyme inhibitor constants. Biochem J 1953;55:170-1.

[19] Jellum E, Borresen HC, Eldjarn L. The presence of furan derivatives in patients receiving fructose-containing solutions intravenously. Clin Chim Acta 1973;47:191201.

[20] Germond JE, Philippossian G, Richli U, Bracco I, Arnaud MJ. Rapid and complete urinary elimination of $\left[{ }^{14} \mathrm{C}\right]$-5-hydroxymethyl-2-furaldehyde administered orally or intravenously to rats. J Toxicol Environ Health 1987;22:79-89.

[21] Godfrey VB, Chen LJ, Griffin RJ, Lebetkin EH, Burka LT. Distribution and metabolism of (5-hydroxymethyl)furfural in male $\mathrm{F} 344$ rats and $\mathrm{B} 6 \mathrm{C} 3 \mathrm{~F} 1$ mice after oral administration. J Toxicol Environ Health A 1999;57:199-210.

[22] Monien BH, Frank H, Seidel A, Glatt HR. Conversion of the common food constituent, 5-hydroxymethylfurfural, into a mutagenic and carcinogenic sulfuric acid ester in the mouse in vivo. Chem Res Toxicol 2009:in press.

[23] Glatt HR. Sulphotransferases. In: Ioannides C, ditor. Handbook of Enzyme Systems that Metabolise Drugs and Other Xenobiotics. Sussex: John Wiley \& Sons, 2002. p. $353-439$. 
[24] Teubner W, Meinl W, Florian S, Kretzschmar M, Glatt H. Identification and localization of soluble sulfotransferases in the human gastrointestinal tract. Biochem $\mathrm{J}$ 2007;404:207-15.

[25] NTP. Toxicology and carcinogenesis studies of furfuryl alcohol (CAS No.98-00-0) in F344/N rats and $\mathrm{B} 6 \mathrm{C} 3 \mathrm{~F}_{1}$ mice (inhalation studies). Natl Toxicol Program Tech Report Series 1999:1-248.

[26] Glatt HR, Meinl W, Kuhlow A, Ma L. Metabolic formation, distribution and toxicological effects of reactive sulphuric acid esters. Nova Acta Leopoldina 2003;329:151-61.

[27] Martel CL, Lara PN. Renal cell carcinoma: current status and future directions. Crit Rev Oncol Hematol 2003;45:177-90. 


\section{Figure legends}

FIG. 1. Structural formula of 5-sulfooxymethylfurfural (SMF).

FIG. 2. Inhibition of human OAT-mediated substrate uptake by SMF. Parental HEK293 cells (open bars) and HEK293-derived cells expressing hOAT1 or hOAT3 (solid bars) were assayed in the presence of SMF $(500 \mu \mathrm{M}$ und $1 \mathrm{mM})$ and in its absence for uptake of $\left[{ }^{3} \mathrm{H}\right] p$ aminohippurate $(10 \mu \mathrm{M} ; \mathrm{A})$ and $\left[{ }^{3} \mathrm{H}\right]$ estrone sulfate $(50 \mathrm{nM}$; B $)$. The treatment was performed at $37^{\circ} \mathrm{C}$ for $2 \mathrm{~min}$. Data are expressed as a percentage of the basal uptake (in the absence of SMF) of the OAT-expressing cells in the corresponding experiment. Values are means and SE of three experiments conducted on separate occasions. The absolute values of the basal uptake $( \pm \mathrm{SE})$ amounted to $178 \pm 12$ and $1.60 \pm 0.14 \mathrm{pmol} / \mathrm{mg}$ protein in $2 \mathrm{~min}$ for hOAT1 ( $p$ aminohippurate) and hOAT3 (estrone sulfate), respectively. ${ }^{*} p<0.05 ; * * p<0.01$, compared to the same cells in the absence of SMF (paired Student's $t$-test using the absolute uptake as the statistical unit).

FIG. 3. Kinetic analyses of the influence of SMF on organic anion uptake by human OAT. Uptake of $\left[{ }^{3} \mathrm{H}\right] p$-aminohippurate $(10 \mu \mathrm{M}$ or $50 \mu \mathrm{M})$ and $\left[{ }^{3} \mathrm{H}\right]$ estrone sulfate $(50 \mathrm{nM}$ or 250 nM) was assayed in HEK293-derived cell lines stably expressing hOAT1 (A) and hOAT3 (B), respectively, in the presence of varying concentrations of SMF for $1 \mathrm{~min}$ at $37^{\circ} \mathrm{C}$. Uptake was also determined in control cells. This value was subtracted from that observed in OATexpressing cells. Data are presented as Dixon plots. Values are means \pm SE of three wells from a single representative experiment. The following $K_{\mathrm{i}}$ values were calculated from the plots: $248 \mu \mathrm{M}$ for hOAT1 and $1530 \mu \mathrm{M}$ for hOAT3. Similar values were obtained in repeat experiments (see main text). 
Fig. 4. Uptake of SMF by human OAT-expressing cells. (A) Control HEK293 cells and HEK293-derived cells that express hOAT1 or hOAT3 were exposed to $250 \mu \mathrm{M}$ SMF for varying time periods. After washing and lysing the cells, the intracellular levels of SMF were determined using UPLC-MS/MS. Each value represent the mean \pm SE of six cell cultures. (B) Control and hOAT-expressing cells were exposed to $250 \mu \mathrm{M}$ SMF for $10 \mathrm{~min}$ in the absence or presence of OAT inhibitor probenecid $(1 \mathrm{mM})$. Data are expressed as a percent of the uptake into control (parental HEK293) cells in the absence of probenecid. Values are means \pm SE of three experiments conducted on separate occasions. The absolute uptake of SMF into control cells amounted to $18.7 \pm 4.1 \mathrm{nmol} / \mathrm{mg}$ protein in $10 \mathrm{~min} .{ }^{*} p<0.05$ compared to control cells in the absence of probenecid (paired Student's $t$-test).

FIG. 5. Cytotoxicity of SMF in control and human OAT-expressing cells. HEK293-derived cells were treated with varying concentrations of SMF for $1 \mathrm{~h}$. Cell proliferation was assayed by the incorporation of $\left[{ }^{3} \mathrm{H}\right]$ thymidine $(1 \mathrm{~h})$. Data are expressed as a percentage of $\left[{ }^{3} \mathrm{H}\right]$ thymidine incorporation of the corresponding cell line in the absence of SMF. Values are means of three independent experiments \pm SE. ${ }^{*} p<0.05,{ }^{* *} p<0.01$ (Student's t-test) in comparison with control cells exposed to the same level of SMF.

FIG. 6. Effect of co-incubation of probenecid, an OAT inhibitor, with SMF on the proliferation of control and hOAT-expressing cells. HEK293-derived cells were treated with $400 \mu \mathrm{M}$ SMF in absence or the presence of $1 \mathrm{mM}$ probenecid for $1 \mathrm{~h}$. Cell proliferation was assayed by incorporation of $\left[{ }^{3} \mathrm{H}\right]$ thymidine $(1 \mathrm{~h})$. Data are expressed as a percentage of $\left[{ }^{3} \mathrm{H}\right]$ thymidine incorporation of the corresponding cell line in the absence of SMF. Values 
represent means $\pm \mathrm{SE}$ of three independent experiments. ${ }^{*} p<0.05$ (Student's t-test) in comparison with corresponding cells without probenecid. 
Figure_1

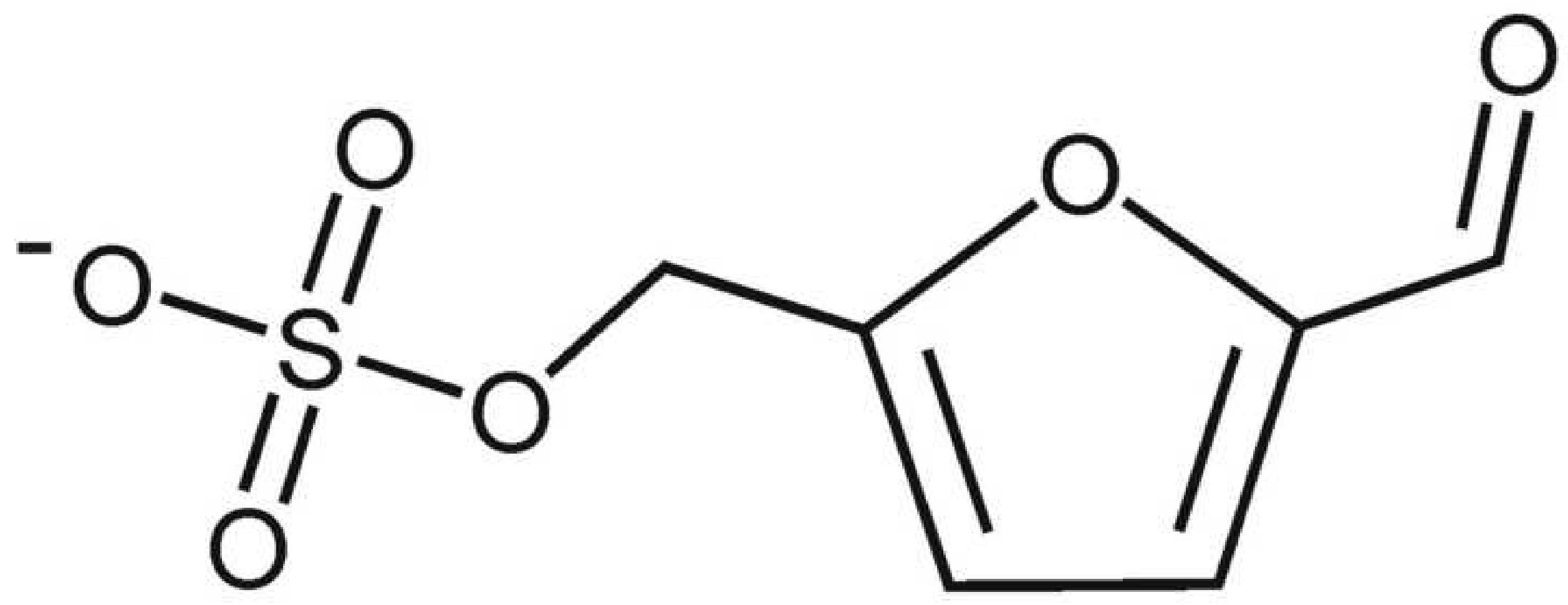

Page 23 of 28 
A

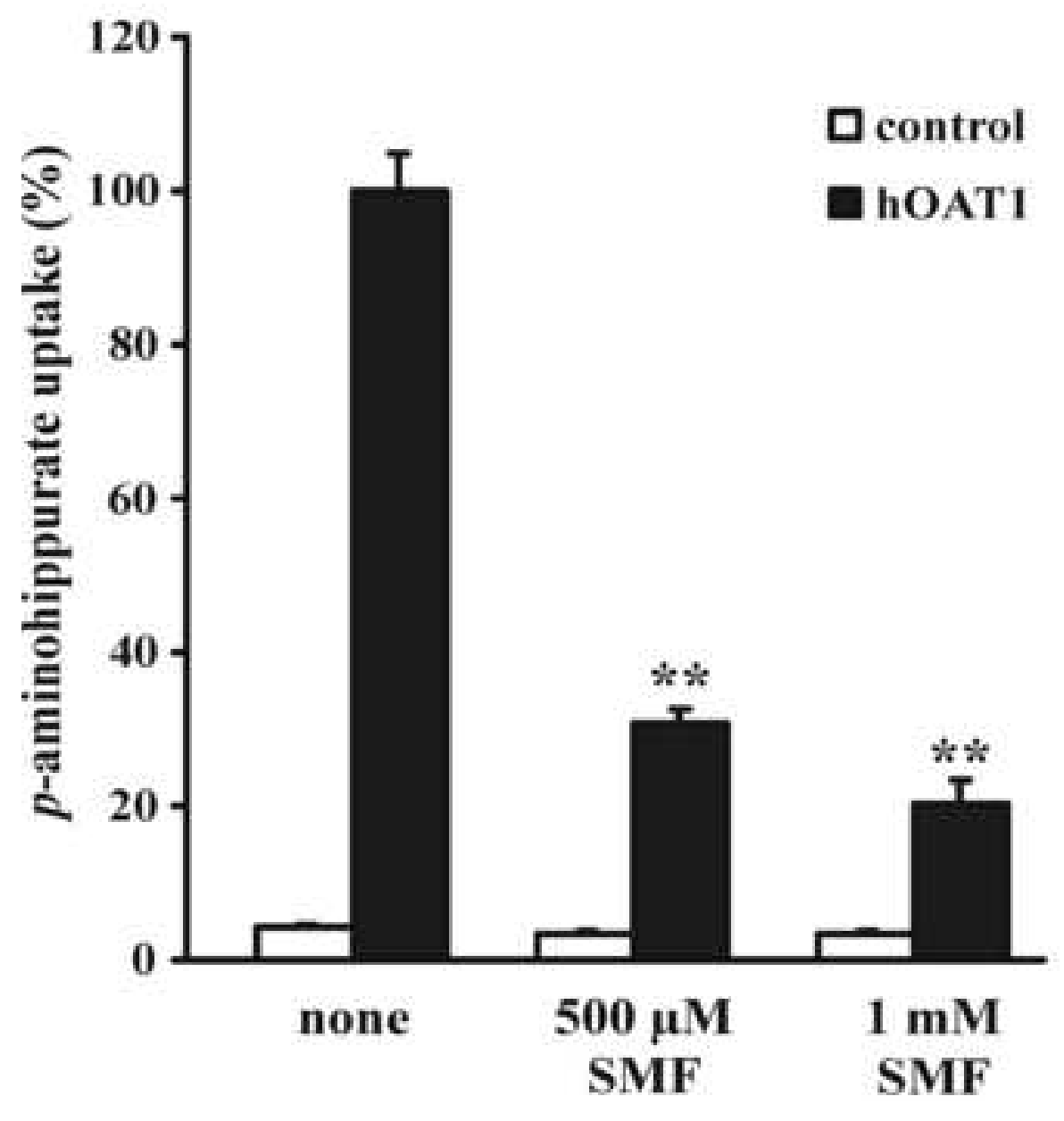

\section{B}

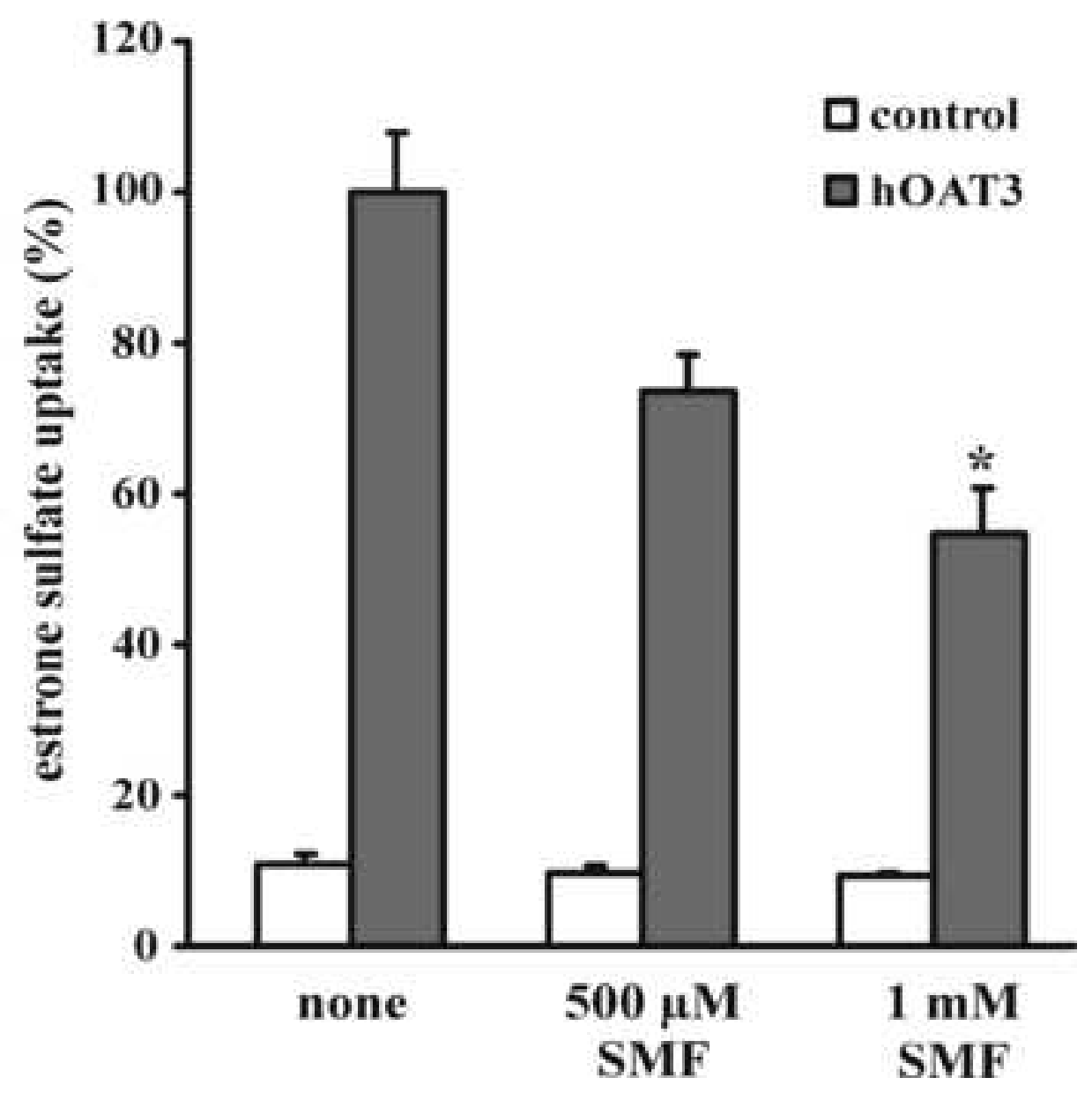


A, hOAT1

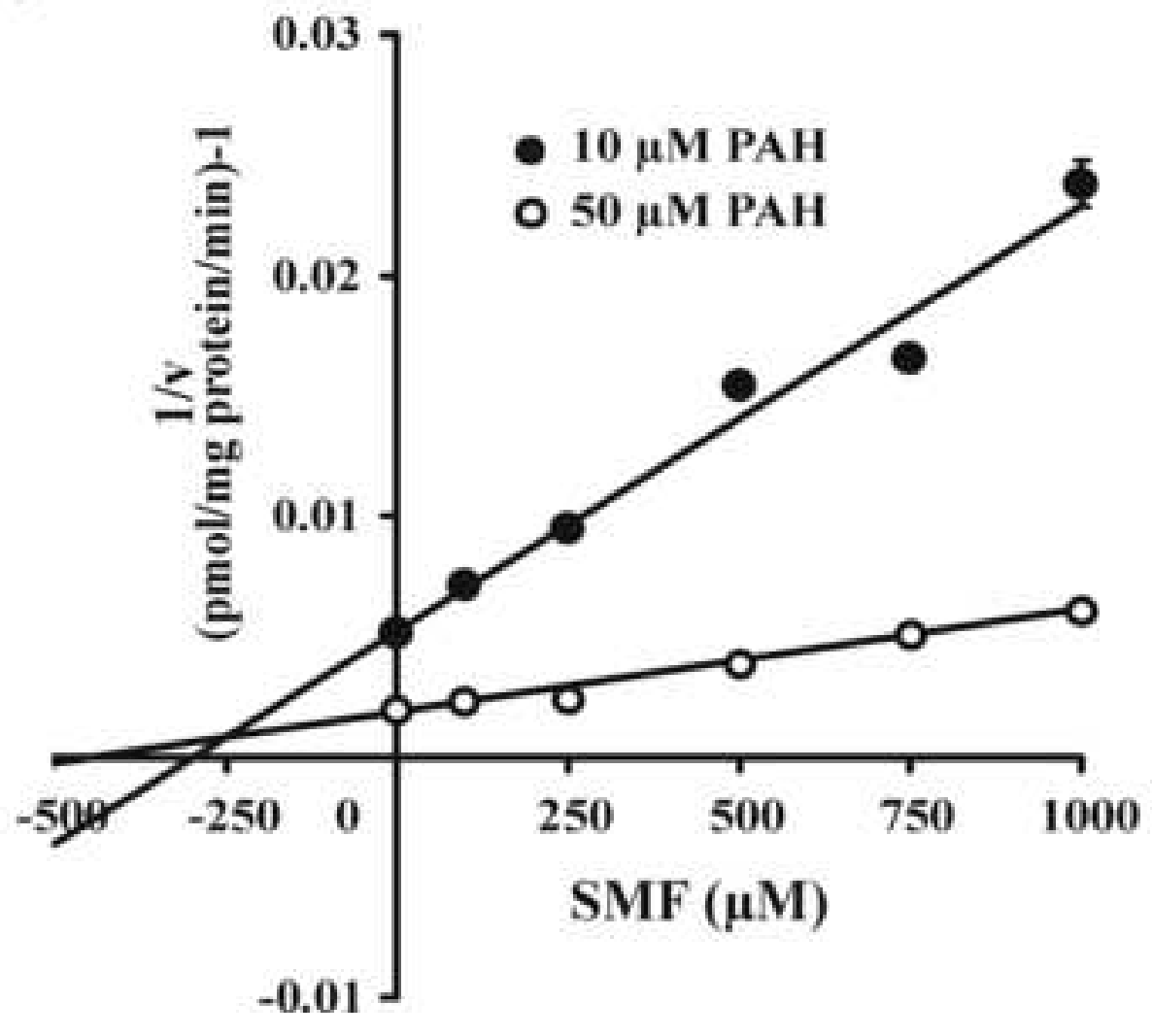

B, hOAT3

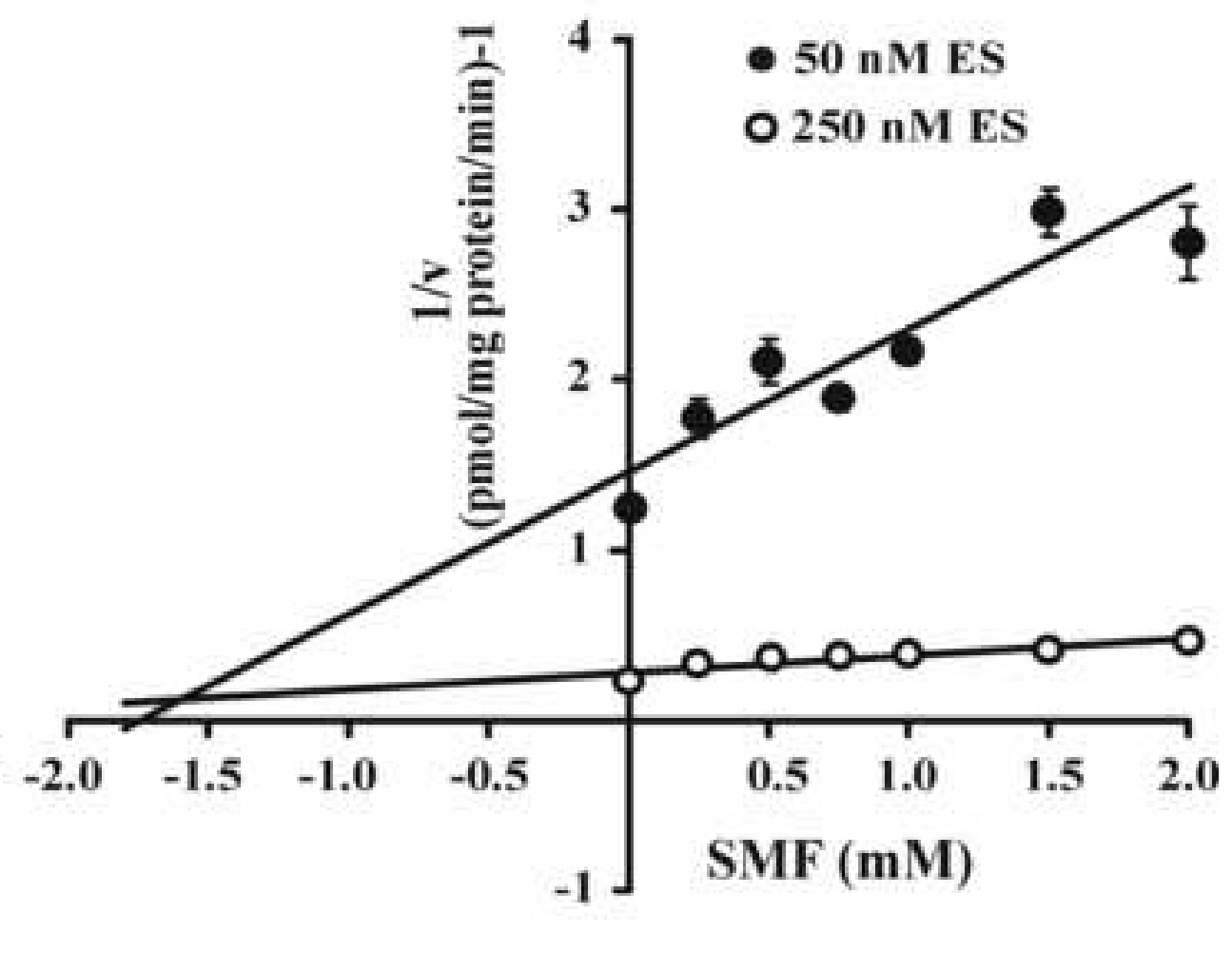



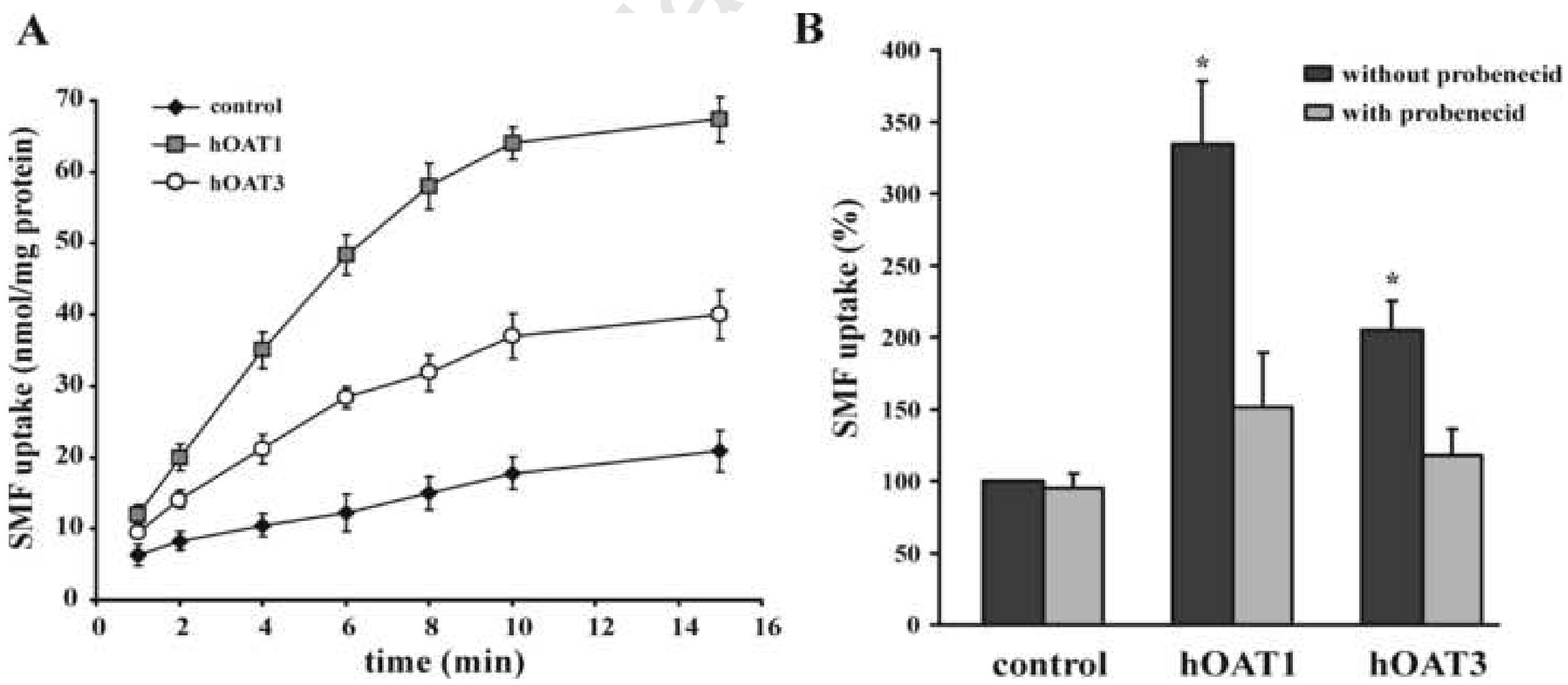


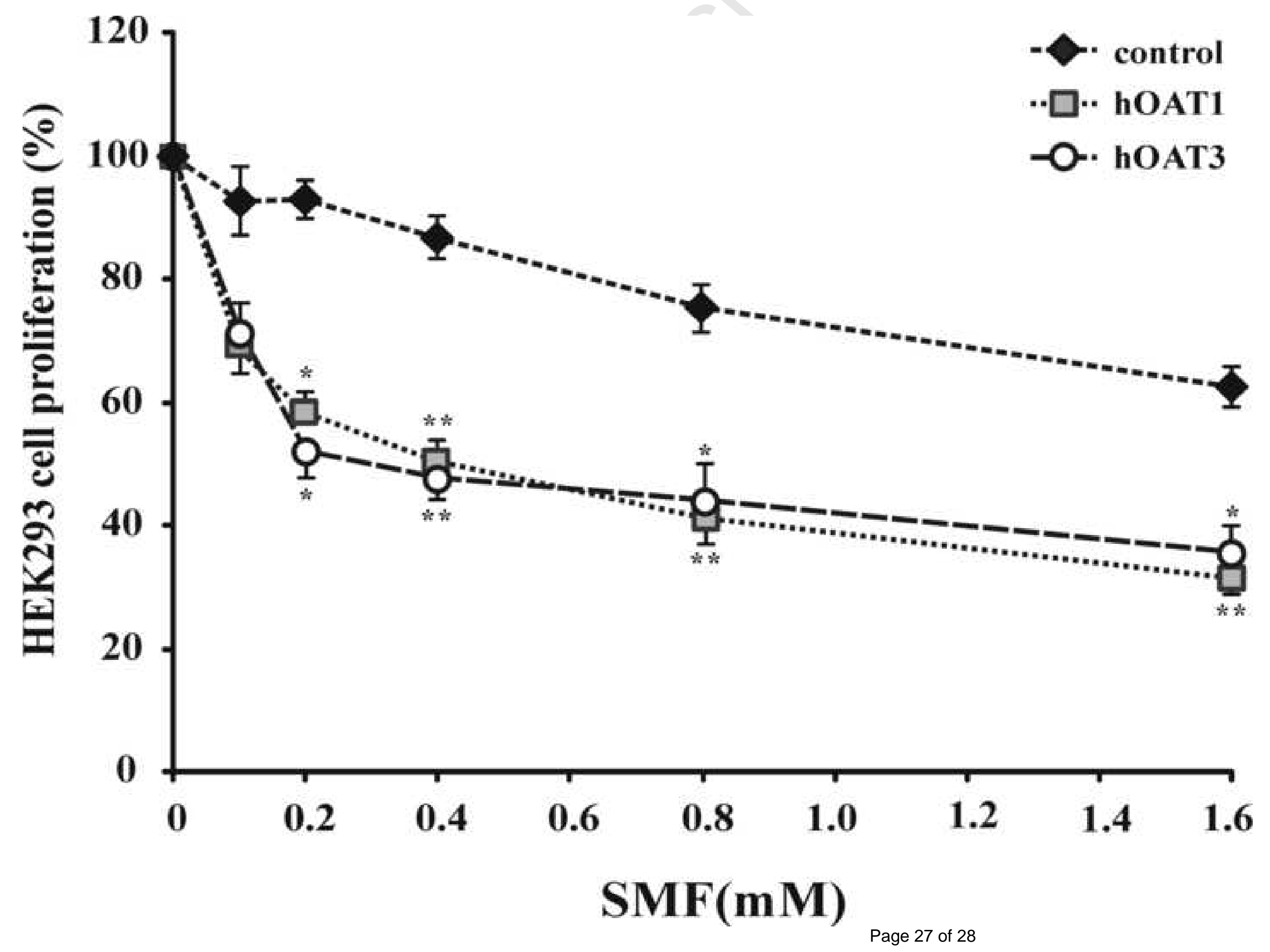




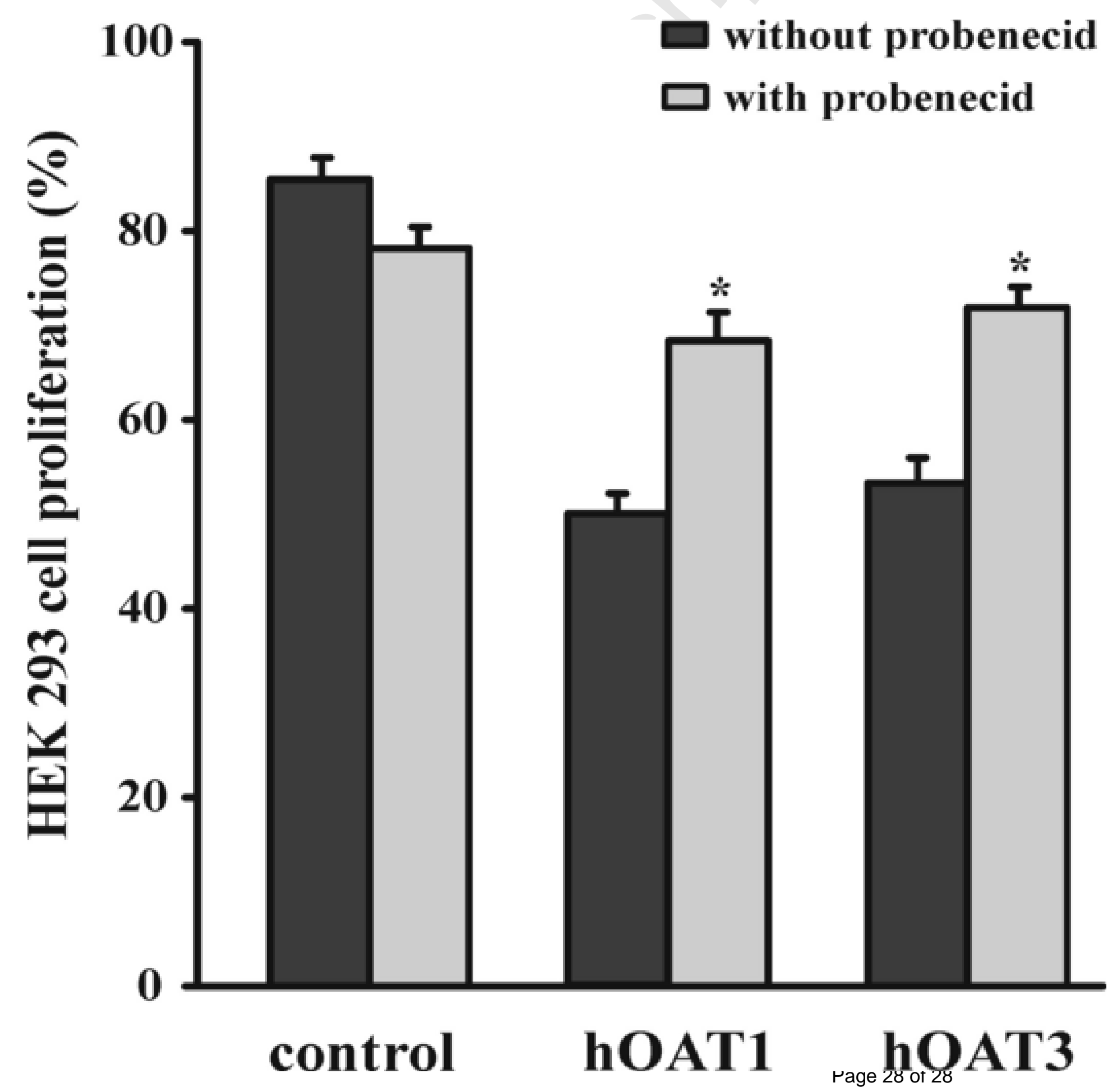

